\title{
Measurements of HbA1c by High Performance Liquid Chromatography in D-10 analyzer and Immunological Method by Beckman Coulter AU480 System: A Comparative Study
}

\author{
Md. Aminul Haque Khan ${ }^{1}$, Mst. Rokshana Rabeya ${ }^{2}$, Muhammad Saiedullah ${ }^{3}$
}

\begin{abstract}
Background: $H b A_{l c}$ can be measured by different methods. Enzymatic, boronate affinity chromatographic and cation-exchange high performance liquid chromatographic (HPLC) methods are considered as gold standard methods. To make the test cost-effective many laboratories use the immunological method installed in a chemistry analyzer. Objective: To compare the values of $\mathrm{HbA}_{1 c}$ measured by high performance liquid chromatographic method and immunological method in two laboratory settings. Materials and Methods: This observational and comparative study was conducted in Bangladesh Institute of Health Sciences (BIHS) and Enam Medical College, Savar, Dhaka. HbA ${ }_{1 c}$ levels measured by HPLC in BIHS were compared with that measured by immunological method in Enam Medical College, Savar, Dhaka. $p$ values $<0.05$ were considered significant. Results: Statistically no difference was observed in mean $\mathrm{Hb} A_{1 c} \%$ between two methods in $\leqslant 7.0 \% \mathrm{Hb} A_{1 c}$ group and 7.1-10.0\% $\mathrm{HbA}_{1 \mathrm{c}}$ group. Significant statistical difference was found in mean $\mathrm{Hb} \mathrm{A}_{1 \mathrm{c}}>10.0 \%$ group, but it was within acceptable limit. Conclusion: $H b A_{1 c}$ can be measured by immunological method installed in an automated chemistry analyzer to make the test costeffective. But HPLC method is preferable.
\end{abstract}

Key words: High performance liquid chromatographic method, Immunological method, $\mathrm{Hb}_{1 c}$

J Enam Med Col 2012; 2(2): 62-66

\section{Introduction}

Diabetes mellitus is a syndrome of impaired carbohydrate, fat and protein metabolism caused by either lack of insulin secretion or decreased sensitivity of the tissues to insulin. ${ }^{1}$ It is characterized by hyperglycemia resulting from the body's inability to utilize glucose for energy. In type 1 diabetes, the pancreas cannot produce insulin and glucose in the blood cannot get entry inside the cell to be metabolized to provide energy. In type 2 diabetes, either the pancreas cannot produce enough insulin or the tissues of the body are insensitive to insulin. The complications of diabetes, involving the eyes, kidneys, nerves and blood vessels of heart, brain, extremities are common to both types of diabetes. ${ }^{2}$ Currently more than $5 \%$ of the world populations are affected by diabetes and it is getting more and more epidemic. ${ }^{3}$

Management of diabetes requires the long term maintenance of blood glucose level as close as possible to a normal level to minimize the complications of diabetes. Blood glucose measurement is an indication of the patient's immediate past condition (hours). It cannot speak of the true status of blood glucose regulation. An accurate index of the mean blood glucose concentration may be obtained

1. Professor, Department of Biochemistry, Enam Medical College, Savar, Dhaka

2. Scientific Officer, Biochemistry Laboratory, Enam Medical College Hospital, Savar, Dhaka

3. Senior Scientific Officer, Department of Clinical Biochemistry, Bangladesh Institute of Health Sciences, Dhaka

Correspondence Md. Aminul Haque Khan,Email: aminhkhan@yahoo.com 
only by the measurement of $\mathrm{HbA}_{1 \mathrm{c}}$ every two to three months. ${ }^{4-6} \mathrm{HbA}_{1 \mathrm{c}}$ can also be translated to average blood glucose (eAG) to get the approximate plasma glucose level. ${ }^{7}$

$\mathrm{HbA}_{1 \mathrm{c}}$ can be measured by immunological, enzymatic, boronate affinity chromatographic and cation-exchange high performance liquid chromatographic (HPLC) methods. ${ }^{8}$ It can also be measured by electrophoresis. Enzymatic and boronate affinity chromatographic and HPLC methods are considered as gold standard methods to measure $\mathrm{HbA}_{1 \mathrm{c}}$. But it is not possible to install these methods in all laboratory settings, especially in the developing countries like ours. Measurement of $\mathrm{HbA}_{1 \mathrm{c}}$ by electrophoresis is also cumbersome and costly. For $\mathrm{HbA}_{1 \mathrm{c}}$ measurement, many laboratories use the immunological method installed in a chemistry analyzer to make the test cost-effective. We designed this study to compare the values of $\mathrm{HbA}_{1 \mathrm{c}}$ measured by HPLC method and immunological method in two laboratory settings.

\section{Materials and Methods}

This observational and comparative study was done in the department of Clinical Biochemistry, Bangladesh Institute of Health Sciences (BIHS), Dhaka and the department of Biochemistry, Enam Medical College, Savar, Dhaka during the period of July 2011 to December 2011. Sixty specimens for measurement of $\mathrm{HbA}_{1 \mathrm{c}}$ levels by HPLC method in Bangladesh Institute of Health Sciences were included for this study. Twenty specimens had $\mathrm{HbA}_{1 \mathrm{c}}$ level $\leq 7.0 \%, 20$ had 7.1 to $10 \%$ and 20 were of $>10 \%$. These specimens were also measured for $\mathrm{HbA}_{1 \mathrm{c}}$ levels in Enam Medical College Hospital laboratory by immunoassay method. Results by these two methods were compared by appropriate statistical analyses.

\section{HPLC method ${ }^{3}$}

We used the Bio-Rad D-10 ${ }^{\mathrm{TM}}$ Hemoglobin $\mathrm{A}_{1 \mathrm{c}}$ program which is intended for the percent determination of $\mathrm{HbA}_{1 \mathrm{c}}$ in human whole blood. The D-10 Hemoglobin $A_{1 c}$ Program is based on chromatographic separation of $\mathrm{HbA}_{1 \mathrm{c}}$ on a cation exchange cartridge. Separation is optimized to minimize interferences from hemoglobin variants, labile $\mathrm{A}_{1 \mathrm{c}}$ and carbamylated hemoglobin. The D$10^{\mathrm{TM}}$ Hemoglobin $\mathrm{A}_{1 \mathrm{c}}$ program also offers automatic sampling from a primary whole blood tube, followed by sample dilution and an analysis time of three minutes per sample.

The samples are automatically diluted on the D-10 and injected into the analytical cartridge. The D-10 delivers a programmed buffer gradient of increasing ionic strength to the cartridge where the hemoglobin is separated based on their ionic interactions with the cartridge material. The separated hemoglobin then passes through the flow cell of the filter photometer where changes in the absorbance are measured at 415 nanometer wavelength. The D-10 software performs reduction of raw data collected from each analysis. Two-level calibration is used for quantification of the $\mathrm{HbA}_{1 \mathrm{c}}$ values. A sample report and a chromatogram are generated for each sample. The $A_{1 c}$ area is calculated using an exponentially modified Gaussian (EMG) algorithm that excludes the labile $\mathrm{HbA}_{1 \mathrm{c}}$ and carbamylated peak area from the $A_{1 c}$ peak area.

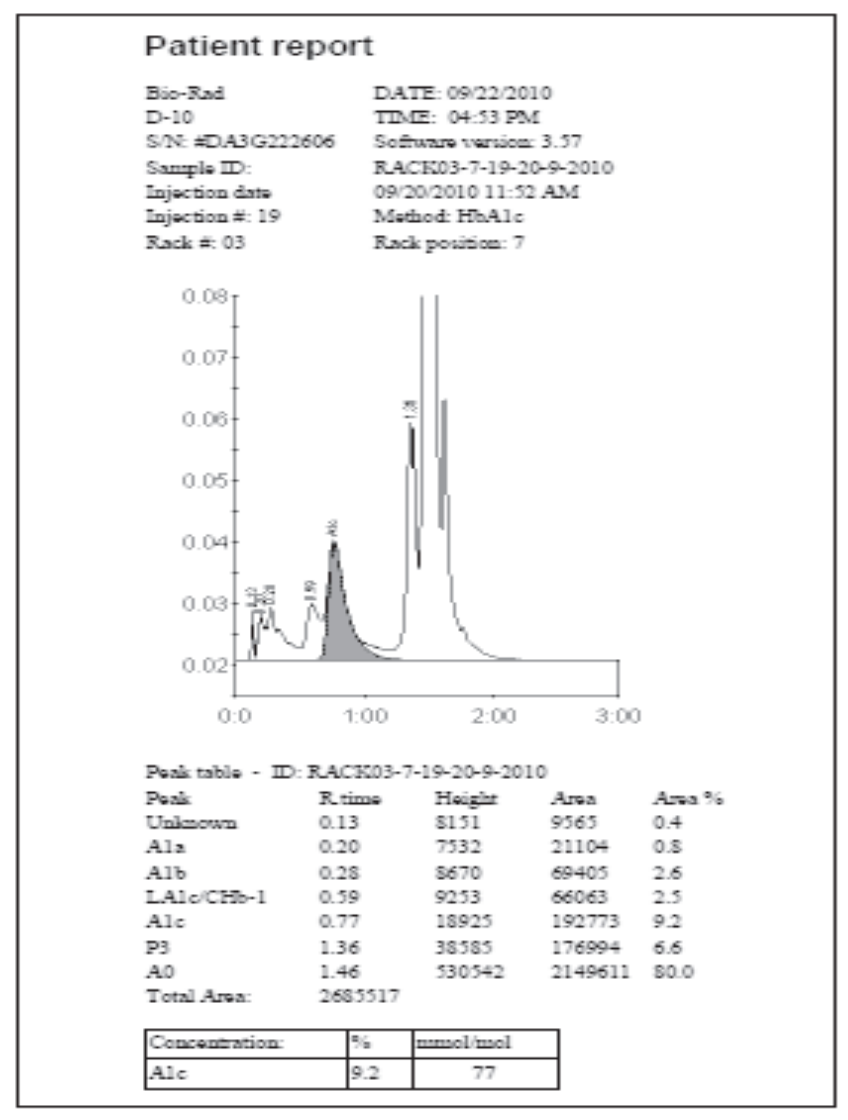

Fig 1. Representative chromatogram of ion-exchange HPLC (shaded area indicates the area of $\mathrm{HbA}_{1 \mathrm{c}}$ eluent) 


\section{Immunoassay $\operatorname{method}^{9}$}

We used the Beckman Coulter AU480 analyzer. The absolute $\mathrm{HbA}_{1 \mathrm{c}}$ and total hemoglobin $(\mathrm{THb})$ values generated as part of the $\mathrm{HbA}_{1 \mathrm{c}}$ assay are intended for the quantitative determination of hemoglobin $A_{1 c}$ concentration as a percentage of total hemoglobin in human whole blood.

The assay for percent $\mathrm{HbA}_{1 \mathrm{c}}$ involves the use of four reagents: Total hemoglobin $\mathrm{R} 1, \mathrm{HbA}_{1 \mathrm{c}} \mathrm{R} 1$ antibody reagent, $\mathrm{HbA}_{1 \mathrm{c}} \mathrm{R} 2$ agglutinator and hemoglobin denaturant. In the pre-treatment step the whole blood is mixed with hemoglobin denaturant in a 1:41 dilution and incubated for a minimum of five minutes at room temperature. The red blood cells are lysed and the hemoglobin chain is hydrolyzed by the protease present in the reagent. Total hemoglobin is measured via the conversion of all hemoglobin derivatives into alkaline hematin in the alkaline solution of a non-ionic detergent. Addition of the pre-treated blood sample to the total hemoglobin reagent results in a green solution which is measured at $600 \mathrm{~nm}$ wavelength. $\mathrm{HbA}_{1 \mathrm{c}}$ is measured in a latex agglutination inhibition assay. An agglutinator, consisting of a synthetic polymer containing multiple copies of the immunoreactive portion of $\mathrm{HbA}_{1 \mathrm{c}}$, causes agglutination of latex coated with $\mathrm{HbA}_{1 \mathrm{c}}$ specific mouse monoclonal antibodies. In the absence of $\mathrm{HbA}_{1 \mathrm{c}}$ in the sample, the antibody-coated microparticles in the $\mathrm{HbA}_{1 \mathrm{c}} \mathrm{R} 1$ and the agglutinator in the $\mathrm{HbA}_{1 \mathrm{c}} \mathrm{R} 2$ will agglutinate. Agglutination leads to an increase in the absorbance of the suspension. The presence of $\mathrm{HbA}_{1 \mathrm{c}}$ in the sample results in a decrease in the rate of agglutination of the $\mathrm{HbA}_{1 c} \mathrm{R} 1$ and the agglutinator in the $\mathrm{HbA}_{1 \mathrm{c}}$ reagent $\mathrm{R} 2$. The increase in absorbance is therefore inversely proportional to the concentration of $\mathrm{HbA}_{1 \mathrm{c}}$ in the sample. The increase in absorbance due to agglutination is measured at $700 \mathrm{~nm}$ wavelength.

\section{Calibration and traceabilty ${ }^{10,11}$}

Calibrator 1 is used for calibration of the total hemoglobin assay. Calibrators 1 to 6 are used for calibration of $\mathrm{HbA}_{1 \mathrm{c}}$ assay. The calibrator $\mathrm{HbA}_{1 \mathrm{c}}$ values are traceable to the International Federation of Clinical Chemistry (IFCC) $\mathrm{HbA}_{1 \mathrm{c}}$ reference method via IFCC $\mathrm{HbA}_{1 \mathrm{c}}$ reference material. Total hemoglobin values assigned to the total hemoglobin calibrator are traceable to the Institute for Reference Materials and Measurements (IRMM) hemoglobin cyanide standard (BCR-522). The relationship between results from the National Glycohemoglobin Standardization Program (NGSP) network (Diabetes Control and Complications Trial, DCCT aligned) and the IFCC network has been evaluated, and a Master Equation, as mentioned below, has been developed for interconversion of results from IFCC to DCCT/NGSP units.

$$
\mathrm{DCCT} / \mathrm{NGSP}=(0.915 \times \mathrm{IFCC})+2.15
$$

Definition of the relationship between the two networks links the IFCC traceable results to clinically meaningful $\mathrm{HbA}_{1 \mathrm{c}}$ results from the DCCT and the United Kingdom Prospective Diabetes Study (UKPDS). The Master Equation also provides these DCCT results with traceabilty to a higher order reference method.

Percent $\mathrm{HbA}_{1 \mathrm{c}}$ results generated during this assay are automatically recalculated to DCCT aligned units by the instrument, using the IFCC approved Master Equation. Results are therefore expressed in DCCT aligned units as recommended by the IFCC.

\section{Statistical analysis}

Statistical analyses were performed by Paired t test, Bland-Altman plot and Pearson's test using MedCalc ${ }^{\circledR}$ version 11.4 for Windows. $p$ values $<0.05$ were considered significant.

\section{Results}

Table I shows the mean $\mathrm{HbA}_{1 \mathrm{c}} \%$ and comparison in different $\mathrm{HbA}_{1 \mathrm{c}}$ levels by two methods. In $\leq 7.0 \%$ $\mathrm{HbA}_{1 \mathrm{c}}$ group it was $6.27 \pm 0.48 \%$ by HPLC method in D-10 analyzer and $6.11 \pm 0.62 \%$ by immunological method in Beckman Coulter AU480 system. In $7.1-10 \% \mathrm{HbA}_{1 \mathrm{c}}$ group it was $8.24 \pm 0.83 \%$ by HPLC method in D-10 analyzer and $8.16 \pm 1.07 \%$ by immunological method in Beckman Coulter AU480 system. In $>10.0 \% \mathrm{HbA}_{1 \mathrm{c}}$ group it was 12.66 $\pm 2.06 \%$ by HPLC method in D-10 analyzer and $11.98 \pm 2.29 \%$ by immunological method in Beckman Coulter AU480 system. 
Table I: Mean $\mathrm{HbA}_{1 \mathrm{c}} \%$ in different $\mathrm{HbA}_{1 \mathrm{c}}$ levels by two methods

\begin{tabular}{lccc}
\hline $\mathrm{HbA}_{1 \mathrm{c}}$ level & \multicolumn{2}{c}{ Methods } & $\mathrm{p}$ values \\
\cline { 2 - 3 } & HPLC & Immunological & \\
\hline $\begin{array}{l}\leq 7.0 \% \\
(\mathrm{n}=20)\end{array}$ & $6.27 \pm 0.48 \%$ & $6.11 \pm 0.62 \%$ & $>0.05$ \\
$7.1-10 \%$ & $8.24 \pm 0.83 \%$ & $8.16 \pm 1.07 \%$ & $>0.05$ \\
$(\mathrm{n}=20)$ & & & \\
$>10.0 \%$ & $12.66 \pm 2.06 \%$ & $11.98 \pm 2.29 \%$ & $<0.05$ \\
$(\mathrm{n}=20)$ & & & \\
\hline
\end{tabular}

for $\mathrm{HbA}_{1 \mathrm{c}}>10.0 \%$. Casewise performance of the two methods in different $\mathrm{HbA}_{1 \mathrm{c}}$ ranges is presented in Fig 3.

\section{Discussion}

In this study we found no significant difference in $\mathrm{HbA}_{1 \mathrm{c}}$ values between the two methods (HPLC in D-10 analyzer and immunological method in Beckman Coulter AU480 system) in $\leq 7.0 \%$ and $7.1-10 \%$ ranges of $\mathrm{HbA}_{1 \mathrm{c}}$ levels. But there was significant difference in $\mathrm{HbA}_{1 \mathrm{c}}$ values between the
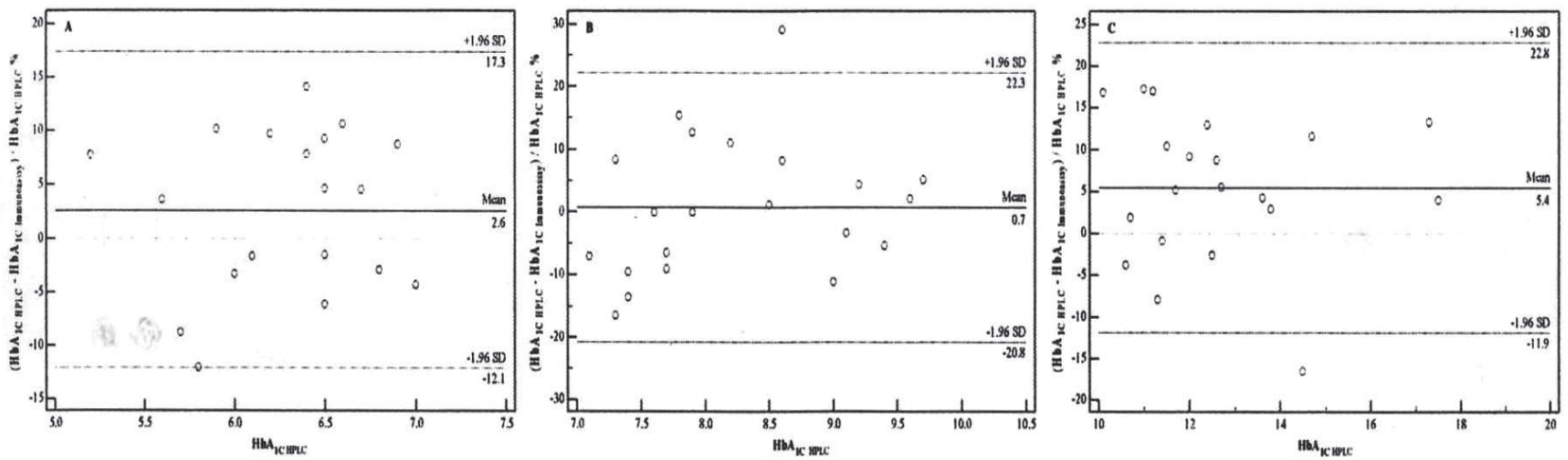

Fig 2. Bias of $\mathrm{HbA}_{1 \mathrm{c}}$ measured by immunological method against HPLC method in $\leq 7.0 \%$ (A), $7.1-10 \%$ (B) and $>10.0 \%(\mathrm{C})$ ranges of $\mathrm{HbA}_{1 \mathrm{c}}$ levels
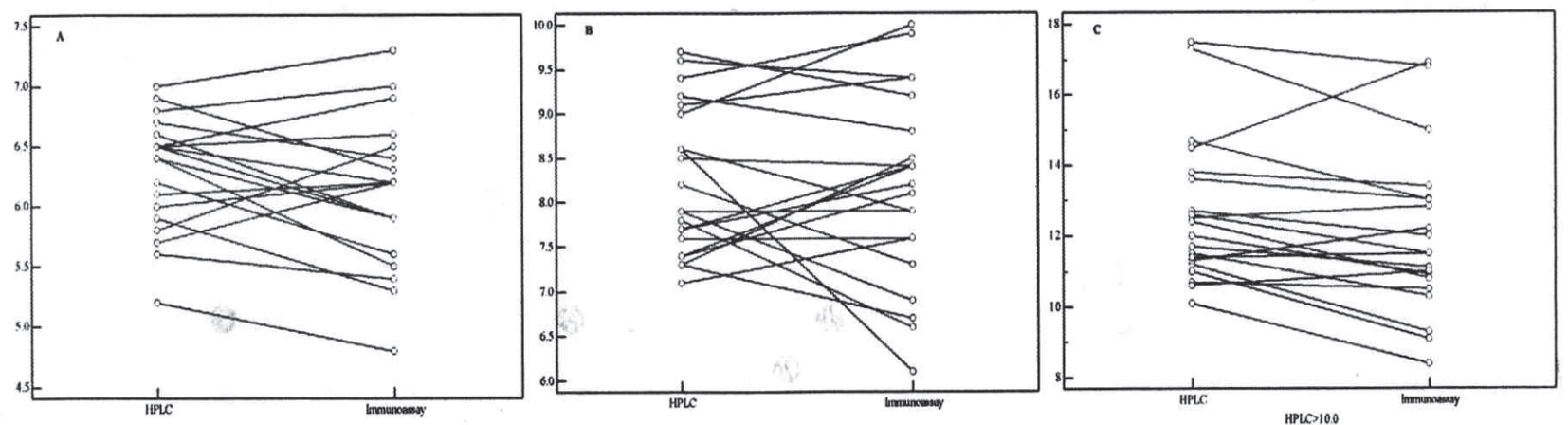

Fig 3. Casewise performance of HPLC and immunological methods to measure $\mathrm{HbA} 1 \mathrm{c}$ in $\leq 7.0 \%$ (A), $7.1-10 \%(\mathrm{~B})$ and $>10.0 \%(\mathrm{C})$ ranges of $\mathrm{HbA}_{1 \mathrm{c}}$ levels

The bias of $\mathrm{HbA}_{1 \mathrm{c}}$ measured by immunological method against the $\mathrm{HbA}_{1 \mathrm{c}}$ measured by HPLC method was $2.6 \%$ for $\mathrm{HbA}_{1 \mathrm{c}} \leq 7.0 \%, 0.7 \%$ for $\mathrm{HbA}_{1 \mathrm{c}}$ range of $7.1-10 \%$ and $5.4 \%$ for $\mathrm{HbA}_{1 \mathrm{c}}>10 \%$ (Fig 2). The correlation coefficients of $\mathrm{HbA}_{1 \mathrm{c}}$ measured by HPLC and immunoassay were 0.671 $(\mathrm{p}=0.0017)$ for $\mathrm{HbA}_{1 \mathrm{c}} \leq 7.0 \%, 0.588(\mathrm{p}=0.0050)$ for $\mathrm{HbA}_{1 \mathrm{c}}$ range of $7.1-10.0 \%$ and $0.870(\mathrm{p}<0.0001)$ two methods (HPLC in D-10 analyzer and immunological method in Beckman Coulter AU480 system) in $>10.0 \%$ range. But in these cases the percentage of difference against HPLC method was $5.4 \%$ which was very close to acceptable limit of $5 \%$. Moreover the correlation coefficients between these two methods were strong in different $\mathrm{HbA}_{1 \mathrm{c}}$ ranges. It was also evident from the casewise 
performance of the two methods that there was no systemic underestimation or overestimation, values of $\mathrm{HbA}_{1 \mathrm{c}}$ were randomly scattered around the $\mathrm{HbA}_{1 \mathrm{c}}$ values measured by HPLC methods. So, it can be concluded that by having proper and regular calibration and by undertaking strict quality control measures in accordance with good laboratory practices $\mathrm{HbA}_{1 \mathrm{c}}$ can also be measured by immunological method installed in a chemistry analyzer to make the test cost-effective. However, more studies in different laboratory settings are recommended.

\section{References}

1. Hall JE. Insulin, glucagon and diabetes mellitus. In: Guyton and Hall textbook of medical physiology. $12^{\text {th }}$ edn. Philadelphia: Saunders, 2011: 939-954.

2. Diabetes in the 1980's. Challenges for the future: Report of National Diabetes Advisory Board; NIH Publication No. 82-2143; US department of health and human service, National Institute of Health: Washington DC, 1982.

3. D-10 Hemoglobin $\mathrm{A}_{1 \mathrm{c}}$ program instructuion manual L20012103, December 2004; Bio-Rad Laboratories, United States.

4. Forshan PH. Diabetes mellitus: a rational plan for management. Postgrad Med 1982; 71: 139-154.
5. Hollander P. The case for tight control in diabetes. Postgrad Med 1984; 75: 80-87.

6. Nathan DM, Singer DE, Huxthal K, Goodson JD. The clinical information value of the glycosylated hemoglobin assay. N Engl J Med 1984; 310: 343-346.

7. Nathan DM, Kuener J, Borg R, Zheng H, Schoenfeld D, Heine RJ. The $\mathrm{A}_{1 \mathrm{c}^{-}}$derived average glucose (ADAG) study group. Translating the $\mathrm{A}_{1 \mathrm{c}}$ assay into estimated average glucose values. Diabetes Care 2008; 31: 14731478.

8. Saiedullah M, Rahman MR, Khan MAH. Uncontrolled diabetic subject with no $\mathrm{HbA}_{1 \mathrm{c}}$ value - a case report. Medicine today 2011; 23(1): 60-61.

9. Manual of Beckman Coulter automated chemistry analyzer AU480, BLOSR6×92.02. 2009-12; Beckman Coulter.

10. Jeppsson J-O, Kobold U, Barr J, Finke A, Hoezel W, Hoshino $\mathrm{T}$ et al. Approved IFCC reference method for the measurement of $\mathrm{HbA}_{1 \mathrm{c}}$ in human blood. Clin Chem Lab Med 2002; 40(1): 78-89.

11. Hoezel W, Weykamp C, Jeppsson J-O, Meidema, Barr JR, Goodall I et al. IFCC reference system for measurement of hemoglobin $\mathrm{A}_{1 \mathrm{c}}$ in human blood and the national standardization schemes in the United States, Japan, and Sweden: a method-comparison study. Clin Chem 2004; 50(1): 166-174. 